\title{
Research on the Application Path of Zaozhuang's Red Culture Gene in the City's Sustainable Development
}

\author{
Zhang Xianxi \\ School of Communication Zaozhuang Universityy
}

\begin{abstract}
Red culture has always constituted an essential part of Zaozhuang, a coal city, in its push for development. Therefore, the coal city is always stamped with the label of red culture. And in the sustainable development of Zaozhuang city, red culture can remain as a new economic growth driver. Red culture can stimulate economic growth by creating a red cultural and creative park, implementing a red gene + project, building a party education base, publishing a series of red cultural readings and so on.
\end{abstract}

Keywords-Red culture; Cultural gene; Sustainable development; Cultural creativity; Cultural works

\section{INTRODUCTION}

Zaozhuang is a coal city, whose economic development stamina continues to be weak with the large amount of coal mining. In 2009, Zaozhuang was designated as a resourceexhausted city by the State Council. With the support of special funds from the State Council and the unremitting efforts of its successive leaders and people, Zaozhuang has found a transformation path of a resource-exhausted city: vigorously developing the modern tourism industry led by Taierzhuang Ancient City, Honghe Wetland, Baodugu National Forest Park and Xiongershan National Geopark, and the modern agricultural industry guided by the "One Bucket of Oil" theory. With the development of these industries. With the development of these industries, Zaozhuang has gradually shaken off the predicament of relying entirely on the coal industry, and has explored a successful way for the sustainable development of resource-exhausted cities [1-2].

In the historical process of the birth and generation of coal city of Zaozhuang, red culture has always been accompanied by it. So red culture has become an important label for the coal city. Therefore, it is not only necessary to implant red culture in the sustainable development of Zaozhuang city, or develop red culture industry, but also can create new economic growth point. Exploring the application of Zaozhuang red culture in the sustainable development of Zaozhuang has become an important research topic for the economic development of Zaozhuang in the new era [3].

Shandong, as a pilot province of new and old kinetic energy conversion in China, has clearly put forward ten major industries for docking new and old kinetic energy conversion. These industries include cultural industry, tourism industry, information industry, high-end equipment manufacturing, highend chemical industry, energy raw materials, marine economy,

This paper Zaozhuang Social Sciences Association Applied research results. modern agriculture, health care, modern finance. Zaozhuang can link up high-end chemical industry, high-end equipment manufacturing, tourism industry and cultural industry according to local conditions, create demonstration zones of resource-based cities' innovative transformation to sustainable development and national sustainable development agenda innovation demonstration zones. The industry closely related to this topic is the cultural industry. The development of cultural industry in Zaozhuang can not do without red culture, the most distinctive cultural label of Zaozhuang. The specific path of red culture in Zaozhuang's sustainable development can be summarized as follows:

\section{CReAting A Red CUltural AND CREATIVE INDUSTRIAL PARK}

Zaozhuang is rich in cultural resources, including the ancestor culture (Dongyi culture) of more than 7000 years, the city-state culture of more than 4000 years, the canal culture (Taierzhuang ancient city) of more than 2000 years, the industrial culture (Zhongxin Cop.) of more than 100 years, and the red culture of nearly 100 years. If these rich cultural resources are properly utilized, they can not only help the economic development of Zaozhuang, but also become the cultural card of Zaozhuang. Building Zaozhuang's cultural and creative industry park is an effective way and method.

The concept of cultural creative industry park was originally derived from the concept of cultural park proposed by Derrick Wayne. Derrick Wayne believes that cultural parks are located in a specific geographical location, where the cultural and recreational facilities of a city are concentrated in the most centralized way, thus promoting cultural production and consumption within the park. The concept of cultural industry creative park then appeared, which was defined by western scholars (Nolapot Pumhiran and Wansborough \& Mageean) as a limited space with obvious geographical areaa place with high concentration of cultural industry and facilities. It is a place where cultural enterprises and creative individuals run or create freely by themselves, as well as playgrounds for children, libraries, open and informal entertainment venues.

Due to historical and practical reasons, the concept of cultural and creative industrial parks appeared relatively late in China, and its definition is still unclear. But in practice, there are also related concepts such as art parks, creative industrial parks, cultural industrial parks and so on. However, the research on cultural and creative industry park has lagged 
behind, so far there is no consensus on the concept of cultural and creative industry park in China. Based on the definition of foreign scholars and the definition of domestic practice and related concepts, we can define the cultural creative industry park as: a special geographical area which gathers a series of cultural industries. This area should have a distinct cultural identity, and produce a certain attraction to the outside world of cultural production, trade, leisure and perform as a multifunctional park with residence as a whole. From this concept we can easily realize that Zaozhuang's rich cultural resources, especially the unique red cultural resources is the cultural creative industry park's distinctive cultural identity. Therefore, Zaozhuang already has the unique natural conditions for the establishment of cultural and creative industrial parks. If the cultural and creative industry park is to be built, the next step should be the demonstration of cultural and creative industry park and the demonstration of future planning and other related issues. Finally, a cultural industry chain including production-distribution - consumption and so on will be formed in the park.

According to the history of Zaozhuang, Zaozhuang Cultural Creative Industry Park can be divided into five parks: Ancestor Cultural Industry Park, City-state Cultural Industry Park, Canal Cultural Industry Park, Industrial Cultural Industry Park and Red Cultural Industry Park.As far as the Red Culture Industrial Park is concerned, it can be divided into red culture creative area: Red Culture Experience Zone, Red Culture Education Zone, Red Culture Creative Incubation Zone and so on. Red Cultural Creative Zone is responsible for collecting red cultural materials, carrying out red cultural planning, creative ideas, writing red film and television plays, network plays and so on.Red Culture Experience Zone can use virtual reality technology to make existing Railway Guerrilla Film and Television City, Weishan Lake-Red River Wetland, Eighth Route Army BaoduAnti-Japanese Memorial Garden into VR, AR, 5D movies and other works, or to show Zaozhuang red film and television drama to let tourists experience the red culture of Zaozhuang. And then stimulate tourists' desire to visit or travel on the spot which will promote the development of Zaozhuang's tourism industry. Red Culture Education Zone mainly aims at children, students and Party members and cadres to carry out red research, red party spirit education and so on. Red culture and creative incubation area mainly undertakes red painting, sculpture, photography, film and television drama shooting and production, distribution and sales. The planning and practice of Zaozhuang Red Culture Creative Park is of great significance. It can not only create a distinctive cultural symbol for Zaozhuang, but also promote the development of Zaozhuang's economy through the related red culture experience and cultural products. It can also publicize the city well and let more people know Zaozhuang.

\section{IMPLEMENTATION OF RED GENE+ PROJECT}

The red culture gene of Zaozhuang is not isolated, it is closely related to many industries. Therefore, the implementation of Red Gene+ project also includes many aspects. For example: Red Gene+ tourism, Red Gene+ rural revitalization, Red Gene+ precision poverty alleviation, Red Gene + film and television, Red Gene+ urban transformation, Red Gene+ product, Red Gene+ internet, Red Gene+ education and so on. Red gene + tourism project. Zaozhuang's efforts in Red Gene+ tourism projects are obvious to all. To commemorate the 60th anniversary of the Chinese people's victory in the War of Resistance Against Japan, Zaozhuang has invested 160 million yuan to build a railroad guerrilla film and television city with a total area of $500 \mathrm{mu}$, which is one of the 100 classic scenic spots of red tourism in China. The city has become a red scenic spot. The scenic spot has a collection of folk-custom landscapes, such as "Lunan Folk Museum", "Yihe Tanchang", "Ancient Opera stage", "Taishidi", "Wanfu Tower", "Zhengtai International Commercial Bank", "Three Star Tower", "De Shun Xing Pharmacy", "Pigeon Tower" and "Fang Gun Tower", "Round Gun". Building, "Big Tea House", "Japanese Army Battalion" and other war scenes. It not only reproduces Old Zaozhuang's humanistic and historical features at that time, but also truly records the history of Japanese invasion of Zaozhuang. It creatively planned the "Railway Guerrilla Legend" theatre to perform the legendary stories of railway guerrillas. It can be said that it is a successful Red Gene+ tourism project. But because the project is only an isolated case, although it can be tied to Taierzhuang ancient city, Baodugu and other scenic spots for two-day tours, the actual number of tourists is not ideal. If we want to change this situation and build a red tourism chain, we must enhance the high-tech content of scenic spots.

To build red tourism chain, Red Gene+ rural revitalization is one of them. The report of the Nineteenth National Congress of the Communist Party of China put forward the strategy of rural revitalization, and the leading group of the central rural work compiled the Strategic Plan for the Revitalization of Rural Areas (2018-2022) to implement the spirit of the Nineteenth National Congress of the Party, the Central Economic Work Conference and the Central Rural Work Conference. Therefore, it is promising to transplant red genes into rural revitalization. For example, we can develop rural red tourism routes, build Zaozhuang Red Culture and Tourism Avenue, red folk villages, red farm inns, so that each inn has a beautiful red story, let visitors experience the red tour, listen to the red story, get spiritual comfort. The implementation of this project has also led to another project, namely, red gene + precision poverty alleviation. In the construction of Red Household Inn and Red Folk Village, the government can be targeted to the poor households, so that the poor households have a way to get rich, can help the local poor households out of poverty accurately.

The Red Gene + film and television project is a comprehensive project, which includes not only the construction of the Red Film and Television City, but also the red rural tourism, as well as the red experience economy, but also the inheritance of red film and television stories and the creation and shooting of red film and television works. The 
construction of red film and television city can be used as a tourist attraction as well as a scenic spot for film and television works. The popularity of red film and television shows that the popularity of red movie and TV attractions is flourishing, and the two are win-win. Red gene + urban transformation mainly refers to the sustainable economic transformation by using red culture. In the past, the single economic structure of Zaozhuang depended entirely on coal economy, which made the economic structure of Zaozhuang more diversified. Red gene + product engineering refers to the use of red gene brand to its local products into red quality and connotation or red label. For example, the Zaozhuang Railway Guerrilla Spirit brand is an example of using Zaozhuang Red Gene + products. In short, Zaozhuang's red culture gene can achieve win-win results with many aspects of its economy.

\section{BUILDING A RED CULTURE AND PARTY SPIRIT EDUCATION BASE}

Zaozhuang's red culture is so rich, these rich red culture is our party's rare red education material. Making full use of these materials to carry out party spirit education, Zaozhuang red gene in Zaozhuang sustainable economic development is an important path. Shandong Party Spirit Education Base has Yimeng Party Spirit Education Base, Jining Party Spirit Education Base, Weihai Party Spirit Education Base, as such a rich red culture Zaozhuang can build its own party spirit education base. In this way, together with Yimeng Party spirit education base and Jining Party spirit education base, these bases can be linked together to build the Shandong Party spirit education highland. Zaozhuang Party Spirit Education Base can plan and build the following pavilions: 1, the Railway Guerrilla Exhibition Hall. At present, the Railway Guerrilla Exhibition Hall has begun to take shape in the efforts of Pan Fu'an for nearly 20 years. Pan Fu'an has traveled over a dozen provinces for more than ten years, traveling hundreds of thousands of kilometers. He has collected a great deal of information and materials from the railway guerrillas, including hundreds of signal lights, helmet, firearms, daily necessities, bottles, wine pots, knives and shells of the Japanese invaders. We can use modern science and technology to build the railway guerrilla Pavilion on the basis of the historical data of the railway guerrillas and these objects. 2, Eighth Route Army Baodu Anti-Japanese Memorial Park. This park has built 7 Historical Exhibition Halls including the Memorial Museum of 115th Division of Eighth Route Army, Party Committee of South Shandong, Administrative Office of South Shandong, The Lunnan Military Region and the 115th Division's Political Department, the 115th Division Headquarters, and the Wang Lushui Memorial Hall. Six functional venues, such as Baoqian Opera Club, Eighth Route Army Night School for Resistance Against Japan, Eighth Route Army Clothing Factory, Gun House, Eighth Route Army Cafeteria and Eighth Route Army Grain Workshop, have been built. Basically, these facilities can fulfill the needs of red culture and party spirit education. 3,He Jingzhi Literature Hall. The Museum has an exhibition hall, film and television hall, library, painting and calligraphy hall, multi-functional hall, etc. It comprehensively introduces the brilliant literary achievements of He Jingzhi, vividly displays the style of a poet, opera writer and senior leading cadre. 4, Taierzhuang War Memorial Hall. It is mainly divided into:
Exhibition hall (Exhibition "situation before the war", "glorious prelude war", "brilliant Taierzhuang annihilation war" and "great influence of Taierzhuang victory"), Painting Hall, Film and Television Hall and Panorama Gallery, etc. 5, The Exhibition Hall of Zaozhuang Mining District. The Revolution Exhibition Hall of Zaozhuang Mining District mainly exhibits the remarkable revolutionary history of Chinese National Industry led by the Chinese Communism Party. It can be divided into National Industrial Exhibition Hall, Zaozhuang Mining Union Exhibition Hall, Mining District Party Branch Exhibition Hall and so on. 6, the Anti Japanese Armed Exhibition Hall. It can be divided into Yixian Branch Pavilion, Canal Branch Pavilion, Independent Branch Pavilion, Wenfeng Brigade Pavilion, Sulu Branch Pavilion and Mass Branch Red Pavilion.

\section{Publishing A SERIES OF ReAdings ABOUt ReD CUlTuRE}

Zaozhuang's rich red cultural heritage can be showed not only in the form of physical display to the world, but also in the form of works of art which can be used in the sustainable development of Zaozhuang. In the campaign of new and old kinetic energy transformation launched by Shandong Province, the provincial government has designated the cultural industry as one of the top ten industries of new and old kinetic energy transformation. The development of cultural industry is inseparable from heavy cultural resources. Zaozhuang has rich cultural resources, and these cultural resources play an important role in the transformation of new and old energy. The most important thing in cultural industry is the creation of cultural products. Zaozhuang can completely transform its unique cultural resources into literary works and realize its economic and social value. In the aspect of red culture, we can do something from the following aspects: 1, creating red films and TV dramas. The films about Zaozhuang's red culture have been published at present, such as "Railway Guerrillas", "Railway Flying Tigers", "Big Waves Scouring Sands" and "Down to South"; TV plays including "Railway Guerrillas 1" and "Railway Guerrillas 2". These works are obviously too few for Zaozhuang's large number of red cultural materials. We can create a large number of red films and TV dramas based on Zaozhuang's red cultural materials. For example, we can create a film "Doctor's Art" according to Guo Zihua's deeds, a series of films can be created according to the battle story of 115th Divisions of the Eighth Route Army, and other materials can also be used to create films and TV plays. 2, creatinge red drama or combining local opera with Liu Qin opera. For example, we can put the stories of the railway guerrillas on the stage to create a stage play, "Railway guerrillas," can also create a number of stage plays or local drama based on other stories. 3, creating photography, sculpture and painting works. For example, we can take a series of photographs of red culture, we can also carve a single sculpture of our red heroes or 115th Division's heroes sculpture, etc. We can also create a series of Zaozhuang heroes through painting works of characters. 
Zaozhuang is a hot land of revolution. Our forefathers dedicated their lives, blood and youth to the happiness of the Chinese people and the rejuvenation of the Chinese nation with their ardent blood. They also left precious red cultural resources for future generations. These red cultural resources are not only the spiritual movement of Zaozhuang's urban redevelopment. It can also integrate its genes into the sustainable development of Zaozhuang city and realize the contemporary value of its times. Therefore, there is realistic value and practical significance to explore the role of red culture gene in the sustainable economic development of Zaozhuang. It is also hoped that the city of Zaozhuang will always be flowing red blood, so that red culture will become the most distinctive city label of Zaozhuang.

\section{CONCLUSION}

Red culture has always been accompanied by Zaozhuang, a coal city, in the historical process of its birth and development. Therefore, red culture has become an important label for this coal city. And in the sustainable development of Zaozhuang city, red culture can create a new economic growth point. The path of creating economic growth point can be summarized as follows: creating a red cultural creative park, implementing the red gene + project, creating a party education base, creating a series of red cultural works and so on.

\section{REFERENCES}

[1] Wei Li ,Ma jiang, "Confucian moral spirit in Chinese film", "Contemporary film" [J].2016.2.

[2] Wen Yuan, "The influence of Taoism on Chinese film aesthetics". "Social scientist"[J].2011.2.

[3] Huang Yu; Li Yong. China red and the construction of national image take the movie "Red Sorghum" and the TV play "Liang Jian" as an example, [J]. Contemporary TV, 2014 (5). (In Chinese) 